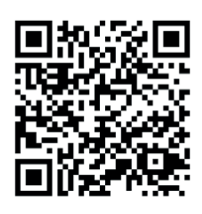

Keywords: Stress

Growth disorder

Dieback

Eucalyptus grandis

Eucalyptus urophylla

Received 30/I I/2017

Accepted 15/03/2018

Correspondence: apcamara0I@gmail.com

Ana Paula Câmaral+, José Tarcísio da Silva Oliveira², Gabrielly dos Santos Bobadilha ${ }^{3}$, Graziela Baptista Vidaurre ${ }^{4}$, Mario Tomazello Filho ${ }^{5}$, Everton Pires Soliman ${ }^{6}$

\title{
PHYSIOLOGICAL DISORDERS AFFECTING DENDROMETRIC PARAMETERS AND EUCALYPTUS WOOD QUALITY FOR PULPING WOOD
}

CÂMARA, A. P.; OLIVEIRA, J. T. S.; BOBADILHA, G. S.; VIDAURRE, G. B.; TOMAZELLO FILHO, M.; SOLIMAN, E. P. Physiological disorders affecting dendrometric parameters and Eucalyptus wood quality for pulping wood. CERNE, v. 24, n. I, p. 27-34, 2018.

\section{HIGHLIGHTS}

The wood volume was the variable more affected by physiological disorders.

The wall cell thickness, fiber length, and vessel diameter were larger in woods from level III of physiological disorder.

The weighted basic density was less affected by physiological disorder.

Pulp yield is influenced by physiological disorder level.

\section{ABSTRACT}

The productive sustainability of eucalyptus planting is threatened when both diseases and disorders of growth occur. These interferences can have abiotic origin as environmental conditions can negatively affect the wood quality. This study has the goal of evaluating influence of different levels of physiological disorders in dendrometric variables and wood quality from seven-year-old Eucalyptus grandis $\mathrm{x}$ Eucalyptus urophylla hybrids intended for wood pulping production. The trees from commercial plantations in State of Maranhão, Brazil were separated into three levels of physiological disorders by means of morphologic changes. Then, they were evaluated according to dendrometric variables, anatomical characteristics, chemical properties, density of wood, and kraft pulp process. The physiological disorder levels significantly influenced all evaluated properties. Moreover, the wood from trees with higher severity of symptoms resulted in higher average values of dendrometric variables, basic density, and fibers dimensions. In addition, apparent density exhibited a different standard in the pith region with increase on radial wood profile. Trees with the least severe disorders exhibited changes in dendrometric and anatomical variables, mainly in wood volume and fibers dimensions, respectively.

I Federal University of Espirito Santo - Jerônimo Monteiro, Espírito Santo, Brazil, ORCID: 0000-000 I-73 I I-2 I 59 2 Federal University of Espirito Santo - Jerônimo Monteiro, Espírito Santo, Brazil, ORCID: 0000-0003-3375-9227

${ }^{3}$ Mississippi State University - Mississippi State, Mississippi, United States of America, ORCID: 0000-0003-4505-8700 ${ }^{4}$ Federal University of Espirito Santo, Jerônimo Monteiro, Espírito Santo, Brazil, ORCID: 0000-000 I-9285-7I 05

${ }^{5}$ University of Sao Paulo, Piracicaba, São Paulo, Brazil, ORCID: 0000-0002-98|4-0778

${ }^{6}$ Suzano Pulp and Paper Company, São Paulo, São Paulo, Brazil, ORCID: 0000-000 I-6220-4568 


\section{INTRODUCTION}

The widespread use of Eucalyptus grandis $\mathrm{x}$ Eucalyptus urophylla hybrids in forest plantation is related to their fast growth, decreased cutting cycle, water deficit resistance, high-density value, and pulp yield from $50 \%$ to $54 \%$ (Santos et al., 2016).However, under controlled conditions of production, trees tend to interact with other environmental factors by an unknown mechanism resulting in either physiological or abiotic disorder (Schutzki; Cregg, 2007). According to these authors, physiological disorders occur as a response to climatic, edaphic, nutritional, agriculture factors, and in some cases genetic predisposition in a plant.

Physiological plant disorders bring changes in stem, leaves, and growth as a cumulative effect of casual factors (Kennelly et al., 2012, Peet, 2016). The advance of plant disorder results in loss of productivity, increase of residue amounts in field and increased damage in mechanized harvest system. These stressful agents can adversely affect the health and condition of trees, resulting in reduced growth and possibly leading to tree death. They can cause a direct loss of leaf tissue through excision, necrotic lesions, premature leaf abscission (defoliation) or a reduction in physiological function (chlorosis). Disorders could also impact the cutting age and require more silvicultural interventions (Stone et al., 2003; Laclau et al., 2013).

The first records of physiological disorder in Brazil were in 2007 in commercial plantations in the State of Espírito Santo and in the South of Bahia (Rodrigues, 2013). The symptoms were described as anomalies in eucalyptus growth associated to interaction with climatic, nutritional, edaphic, and genetics factors, such as high radiation, extreme alternation of relative humidity and soil, and nutritional deficiency. However, wood quality parameters were not evaluated. Other information about physiological disorder is related to the cycle of precipitation, such as frequency and intensity. These factors act as important agents in emergence and latency of symptoms.

Even though some literature mentions physiologic disorder in eucalyptus, studies with in depth knowledge about it and its effects upon forest production, wood quality, and pulp production are rare. Therefore, the goal of this experiment was to evaluate the influence of different levels of physiologic disorders in dendrometric variables and wood quality of Eucalyptus grandis $x$ Eucalyptus urophylla hybrids destined for pulping kraft.

\section{MATERIAL AND METHODS}

Wood samples were obtained from trees of Eucalyptus grandis $x$ Eucalyptus urophylla hybrids at seven years old in commercial plantations of $3 \times 3 \mathrm{~m}$ spacing line in Vila Nova dos Martírios and Imperatriz, cities located in the State of Maranhão Brazil. According to Köppen-Geiger, the weather in both cities is classified as Aw, tropical sub-humid and mesothermic, dry winter and rainfall concentrated in summer, average annual precipitation of $1.227 \mathrm{~mm}$ and average temperature of $25.4^{\circ} \mathrm{C}$. Figure I shows average values of precipitation and temperature from the Imperatriz data.

At four years old (in 20II), trees manifested physiological disorder symptoms with distinct intensities among the same hybrids. The symptom distinctions among hybrids were based on visual criteria, which were established by Suzano Pulp and Paper Company (Figure 2) and ordered in a scale from I to III, according to symptoms severity as described below:

Level I Physiologic Disorder was characterized as mild symptoms in which trees exhibited surficial lesion, cracking and slight detachment of bark, trunk, and branches. Such trees were collected in Vila Nova dos Martírios where the annual precipitation is from 1400 to $1600 \mathrm{~mm}$ and altitude of $240 \mathrm{~m}$.

Level II Physiologic Disorder had intermediary physiological disorder symptoms such as burning of the basal third of crown, bark cracking and tumescence in specific points of stem and branches. These trees were located in Imperatriz, which has annual precipitation from 1500 to $1700 \mathrm{~mm}$ and altitude of $190 \mathrm{~m}$.

Level III Physiologic Disorder was characterized by more severe symptoms which included dieback, loss of apical dominance, witches' broom, stem and leaf edema in trees from Vila Nova do Martírios, which has 1600 to $1800 \mathrm{~mm}$ precipitation and $155 \mathrm{~m}$ altitude.

In this study, there was no sampling from any tree that has not been affected by physiological disorder (i.e., no control). The growing anomaly was detected in every tree in that region totalizing an area of $62.6 \mathrm{ha}$. However, some tests did use the company control that had the same origin and age as the studied trees.

The samples were selected by 10 trees and cut for removing disks along the trunk at base, $\mathrm{DBH}, 25 \%$, $50 \%, 75 \%$, and $100 \%$ of the commercial height of tree.

The collection of trees was made in February 2014 when edaphic sampling for physical and chemical characterization of the soil was also made. The soils from level I and II physiological disorders were classified as Yellow Argisol Tb Dystrophic, class textural medium-sandy, and softy wavy relief. The soil of level III physiological disorder 
was classified as Yellow Latosol Dystrophic, class textural medium, and plain relief (Table I).

Wood volume was estimated from measurements made at $\mathrm{DHB}$ and commercial height on ten trees selected for each level of physiological disorder. Based on this data the individual volume of tree was estimated (with and without bark) using the Smalian method.
Apparent density was determined by an X-ray densitometry technique with distance intervals of 40 $\mu \mathrm{m}$. Five graphics were generated for each level of physiological disorder, but just one graphic was selected that best represented each level according to its radial wood profile.

In order to evaluate wood fiber and vessels, samples were obtained from disks at the DHB position

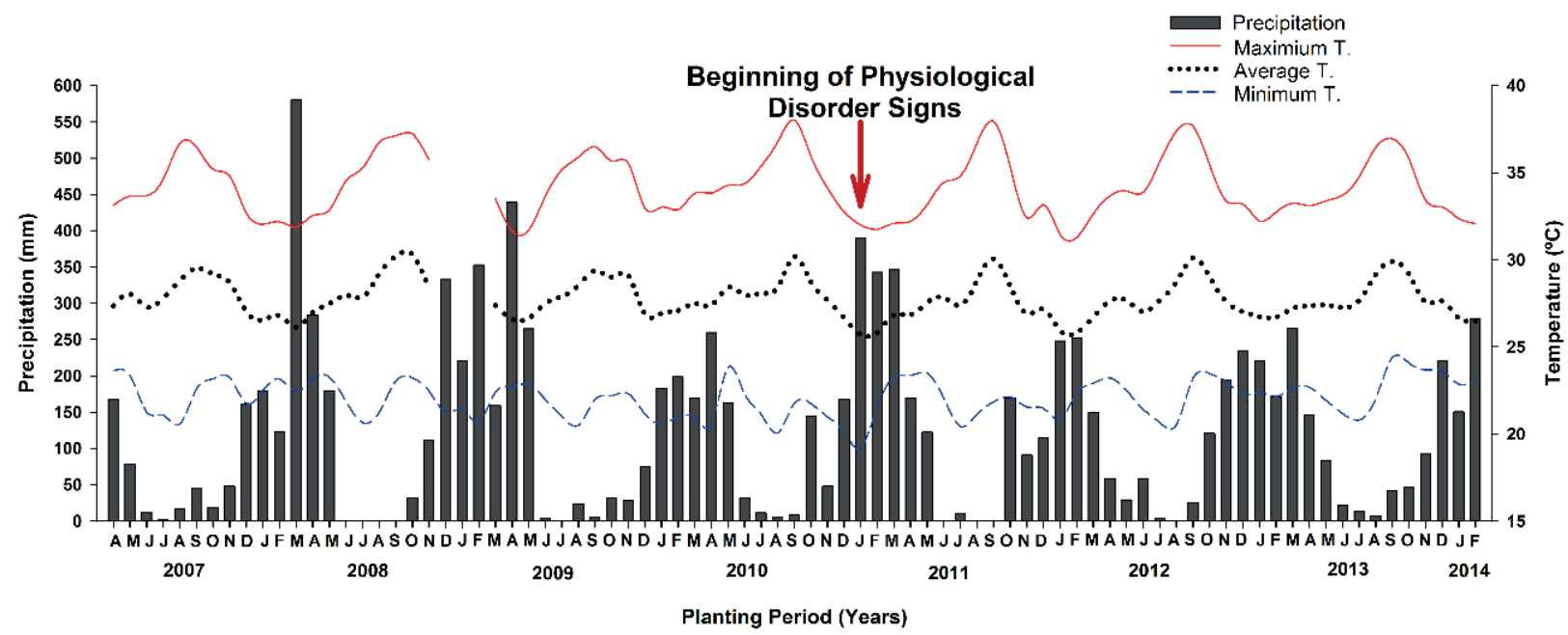

FIGURE I Monthly average of precipitation $(\mathrm{mm})$ and maximum, average and minimum temperature $\left({ }^{\circ} \mathrm{C}\right)$ from April 2007 to February 2014 (Source: INMET). The discontinued temperature line corresponds to periods without report by INMET.

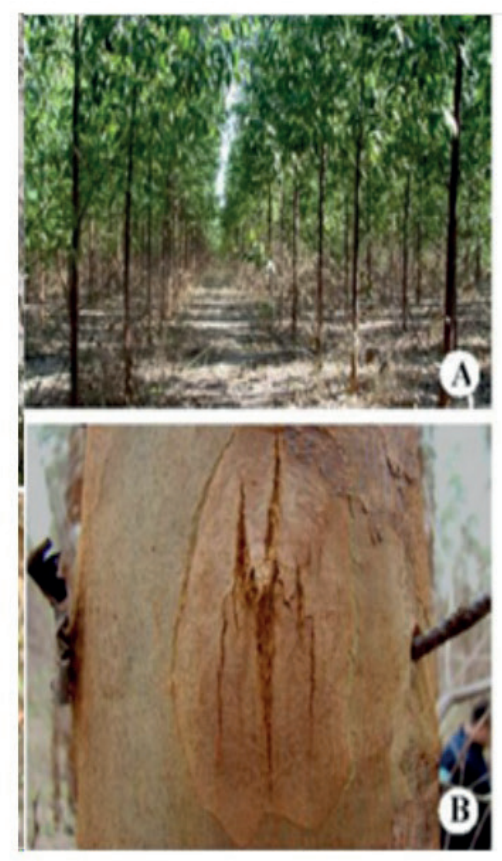

LEVEL I
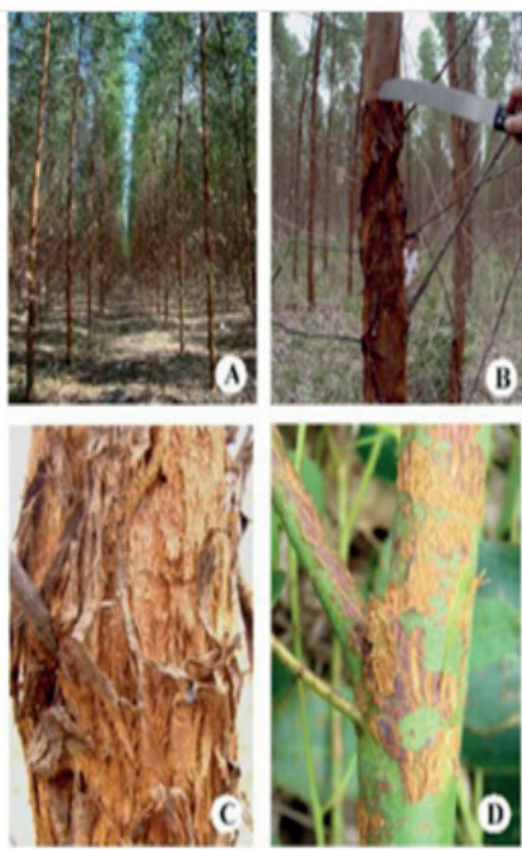

LEVEL II

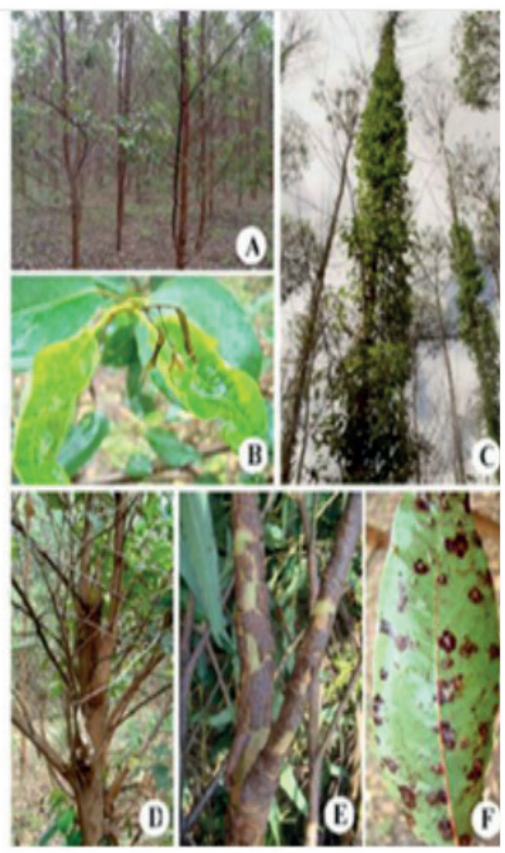

LEVEL III

FIGURE 2 Symptoms of physiological disorders for levels I, II and III. Level I, A: experimental planting, B: bark detachment. Level II, A: experimental planting, B: bark cracking, C: bark tumescence, D: burn in specified point of a stem. Level III, A: experimental planting, B: dieback, C: witches' broom, D: loss of apical dominance, E: stem and leaf edema. Source: Suzano Pulp and Paper Company 
PHYSIOLOGICAL DISORDERS AFFECTING DENDROMETRIC PARAMETERS AND Eucalyptus wood QUALITY FOR PULPING WOOD CERNE

TABLE I Chemical analysis of soil at different levels of physiological disorder.

\begin{tabular}{ccccccccc}
\hline Level of Physiological Disorder & $\begin{array}{c}\text { Depth } \\
(\mathrm{cm})\end{array}$ & $\begin{array}{c}\mathrm{pH} \\
\left(\mathrm{H}_{2} \mathrm{O}\right)^{*}\end{array}$ & $\begin{array}{c}\mathrm{P} \\
\left(\mathrm{mg} \cdot \mathrm{dm}^{-3}\right)\end{array}$ & $\begin{array}{c}\mathrm{SB} \\
\left(\mathrm{mmolc} \cdot \mathrm{dm}^{-3}\right)\end{array}$ & $\begin{array}{c}\mathrm{CEC} \\
(\%)\end{array}$ & $\begin{array}{c}\mathrm{BS} \\
\left(\mathrm{g} \cdot \mathrm{kg}^{-1}\right)\end{array}$ & $\begin{array}{c}\text { Al sat } \\
(\%)\end{array}$ & $\begin{array}{c}\text { SOM } \\
\left(\mathrm{g} \cdot \mathrm{Kg}^{-1}\right)\end{array}$ \\
\hline \multirow{2}{*}{$\mathrm{I}$} & $0-20$ & 4.70 & 2.00 & 9.30 & 47.60 & 19.50 & 30.10 & 12.00 \\
& $20-40$ & 4.60 & 1.60 & 7.20 & 50.70 & 14.20 & 41.00 & 9.00 \\
& $40-60$ & 4.30 & 1.20 & 6.20 & 53.50 & 11.60 & 53.10 & 8.00 \\
\hline \multirow{2}{*}{$\mathrm{II}$} & $0-20$ & 5.60 & 3.20 & 3.40 & 51.90 & 58.60 & 3.20 & 15.00 \\
& $20-40$ & 5.50 & 2.80 & 18.40 & 43.10 & 42.60 & 9.80 & 10.00 \\
& $40-60$ & 5.40 & 2.10 & 14.30 & 42.30 & 33.80 & 17.30 & 8.00 \\
\hline \multirow{2}{*}{$\mathrm{III}$} & $0-20$ & 4.50 & 1.80 & 11.20 & 62.10 & 18.10 & 26.30 & 12,00 \\
& $20-40$ & 4.30 & 1.40 & 8.20 & 61.30 & 13.40 & 37.90 & 9.00 \\
& $40-60$ & 4.20 & 1.10 & 4.20 & 59.00 & 7.10 & 62.60 & 8.00 \\
\hline
\end{tabular}

Extraction methods: $\mathrm{pH}$ in water (I: 2.5); P, K: ** $\mathrm{P}=$ phosphorus; $\mathrm{SB}=$ sum of bases; $\mathrm{CEC}=$ Cation Exchange Capacity; $\mathrm{BS}=\mathrm{Base}$ saturation; Al sat = aluminum saturation; SOM = soil organic matter.

specifically located in the peripheral heartwood region, following the methodology from the Pan American Standards Commission (COPANT, 1974). To obtain the wood vessel and fiber parameters, 25 histological sections were obtained and measured for each sheet.

To evaluate the wood chemicals and kraft pulping, wood chips for each disorder level were analyzed. The methodologies applied for wood chemical characterization were according to Technical Association of the Pulp and Paper Industry (1998) procedures, in particular, wood preparation to chemical test (T264); determination extractives content in acetone (T204); lignin content (T222); and pentosanes content (T223). Inorganics determination (ashes) was made according to the Norma Brasileira Regulamentadora 8I I2/83 (ABNT, 1983). The pulp cooking was made with $6 \mathrm{~kg}$ of chips, previously classified by thickness, moisture of $20 \%$, with digester of forced liquor circulation, and IOL capacity. The delignification occurred following the kraft process into 4:I relation of liquor/wood. The cooking curves and correlation equations were established for estimating yield pulp and rejects that were necessary for this degree of delignification (kappa $18 \pm 0.5$ ). Each level of physiological disorder had a specific consumption determined by using the basic density and screened pulp yield of kraft cooking.

All the quantified variables of wood were tested by univariate analysis of variance (ANOVA) of completely randomized design (CRD). When the variables were significant, the averages were compared by Tukey test $(\alpha=0.05)$, except the kraft pulping which was descriptively analyzed.

\section{RESULTS AND DISCUSSION}

The trees corresponding to level I physiological disorder obtained the lowest means of all dendrometric variables, differing statistically from the other levels (Table 2). The wood volume from level I decreased 55\% when compared to level III.
TABLE 2 Means for dendrometric variables according to physiological disorder levels.

\begin{tabular}{cccccc}
\hline $\begin{array}{c}\text { Levels of } \\
\text { Physiological } \\
\text { Disorder }\end{array}$ & $\begin{array}{c}\text { Total } \\
\text { Height } \\
(\mathrm{m})\end{array}$ & $\begin{array}{c}\text { Commercial } \\
\text { Height } \\
(\mathrm{m})\end{array}$ & $\begin{array}{c}\text { DHB } \\
(\mathrm{cm})\end{array}$ & $\begin{array}{c}\text { Bark } \\
\text { Volume } \\
\left(\mathrm{m}^{3}\right)\end{array}$ & $\begin{array}{c}\text { Wood } \\
\text { Volume } \\
\left(\mathrm{m}^{3}\right)\end{array}$ \\
\hline I & $17.56 \mathrm{~b}^{*}$ & $12.4 \mathrm{I} \mathrm{b}$ & $9.44 \mathrm{~b}$ & $0.00592 \mathrm{~b}$ & $0.0676 \mathrm{~b}$ \\
II & $21.40 \mathrm{a}$ & $16.78 \mathrm{a}$ & $13.34 \mathrm{a}$ & $0.0086 \mathrm{a}$ & $0.1466 \mathrm{a}$ \\
III & $21.28 \mathrm{a}$ & $16.43 \mathrm{a}$ & $14.08 \mathrm{a}$ & $0.0104 \mathrm{a}$ & $0.1530 \mathrm{a}$ \\
\hline F value & 5.67 & 4.49 & 13.97 & 5.38 & 7.68 \\
CV $(\%)$ & 16.59 & 26.52 & 23.65 & 42.09 & 53.56 \\
\hline
\end{tabular}

$\mathrm{DBH}$ : diameter at breast height. *Value followed by the same letter within column are not significantly different by Tukey test $(p>0.05)$. CV: coefficient of variation.

The wood production on trees with physiological disorder levels II and III is likely related to higher precipitation in their soil. In such conditions, the stomata is kept open favoring transpiration and carbon assimilation. As a result, trees increase in growth and biomass accumulation (VELLINI et al., 2008).

The area that produced the level II trees would have contributed to wood increment because that soil had the highest concentration of exchangeable cations $\left(\mathrm{K}, \mathrm{Ca}^{+2}, \mathrm{Mg}^{+2}\right)$. The average acidity and high values of base saturation indicated more fertility that has a positive effect on tree growth (SIMONETE et al., 20I3) such as total height and diameter at breast height.

Level III tree heights were not impaired by some physiological disorder symptoms such as loss of apical dominance and dieback. Possibly, these plants had been invigorated after the symptom diagnosis, or perhaps, the disturbing effect could have occurred progressively. These disorder symptoms may have occurred later near the harvest, and if so, then they would not have significantly interfered with the vertical development of those trees. In addition, trees cultivated in the area with highest precipitation had the effects of physiological disorder softened because of water availability.

Stressed plants tend to increase leaf branching and consequently increase the biomass. The changes in regrowth morphology to increase light capture, chemical defenses combined with increased growth were also multiple responses of $E$. globulus (BORZAK et al., 20I6).

When trees from level I were compared respectively to levels II and III, the diameter losses 
were $29 \%$ and $33 \%$ which evidence the effects of environmental conditions. Evaluating $\mathrm{DBH}$ of seven species from Deciduous Seasonal Forest over 6 years, Chagas et al. (2004) identified diameter variations due to seasonality. They pointed out that in a rainy season bark swelling results in lesions. However, in a dry season water loss causes trunk contraction. The trees from level I physiological disorder likely exhibited this behavior due to low rainfall index, intensifying the seasonal effects.

Levels of physiological disorder significantly impacted the basic density, extractives content, and wood ashes. Woods from level I and III statistically differed, except to ashes content (Table 3). The level III yielded higher values on fibers characteristics and diameter vessel, but the level I had higher vessel number.

Weighted basic density was less affected by physiological disorder. The trees from level III obtained values of basic density similar to other searches involving trees from the same hybrid and at ages of 8 and 7 years old, respectively, under normal condition of growth (GONÇALEZ et al., 20I4; MENESES et al., 20I5).

The extractives were higher in trees from levels I and II. Compared to the highest extractive content having same origin and age, level III physiological disorder trees decreased extractive content by $26.5 \%$. Rodrigues (2013) also observed variation of extractive content in

TABLE 3 Means for wood properties according to physiological disorder level.

\begin{tabular}{|c|c|c|c|c|c|}
\hline \multirow{2}{*}{ Parameters } & \multirow{2}{*}{$\begin{array}{l}\text { CV } \\
\text { (\%) }\end{array}$} & & \multicolumn{3}{|c|}{ Level of Physiological Disorder } \\
\hline & & & 1 & II & III \\
\hline \multicolumn{6}{|l|}{ Weighted basic } \\
\hline $\begin{array}{l}\text { density } \\
\left(\mathrm{g} \cdot \mathrm{cm}^{-3}\right)\end{array}$ & II.29** & 7.24 & $0.437 b^{*}$ & $0.422 \mathrm{~b}$ & $0.491 \mathrm{a}$ \\
\hline Extractives & & & & & \\
\hline $\begin{array}{l}\text { through acetone } \\
\text { (\%) }\end{array}$ & 22.11 & 6.81 & $2.45 \mathrm{a}$ & $2.26 \mathrm{a}$ & $\mathrm{I} .80 \mathrm{~b}$ \\
\hline $\begin{array}{l}\text { Insoluble Lignin } \\
\text { (\%) }\end{array}$ & 2.58 & $0.20 \mathrm{~ns}$ & $24.55 \mathrm{a}$ & $24.60 \mathrm{a}$ & $24.19 a$ \\
\hline $\begin{array}{c}\text { Soluble Lignin } \\
\text { (\%) }\end{array}$ & 6.73 & $4.46 \mathrm{~ns}$ & $3.82 \mathrm{a}$ & $3.76 \mathrm{a}$ & $3.42 \mathrm{a}$ \\
\hline $\begin{array}{l}\text { Total Lignin } \\
(\%)\end{array}$ & 2.52 & $3.91 \mathrm{~ns}$ & $28.37 \mathrm{a}$ & $28.36 \mathrm{a}$ & $27.6 \mathrm{I} a$ \\
\hline $\begin{array}{c}\text { Pentosan Content } \\
\text { (\%) }\end{array}$ & 2.57 & $1.56 \mathrm{~ns}$ & $15.05 \mathrm{a}$ & $14.65 \mathrm{a}$ & $15.05 \mathrm{a}$ \\
\hline $\begin{array}{c}\text { Ashes Content } \\
(\%)\end{array}$ & 29.78 & 4.67 & $0.30 \mathrm{a}$ & $0.20 \mathrm{~b}$ & $0.23 \mathrm{ab}$ \\
\hline \multicolumn{6}{|l|}{ Cell Wall } \\
\hline $\begin{array}{l}\text { Thickness } \\
(\mu \mathrm{m})\end{array}$ & 44.72 & 52.68 & $3.64 \mathrm{c}$ & $4.93 \mathrm{~b}$ & $5.35 \mathrm{a}$ \\
\hline $\begin{array}{l}\text { Fiber Length } \\
\qquad(\mu \mathrm{m})\end{array}$ & 38.14 & 50.53 & $976.36 c$ & I203.I b & $1353.3 \mathrm{a}$ \\
\hline $\begin{array}{l}\text { Vessel Diameter } \\
\qquad(\mu \mathrm{m})\end{array}$ & 23.06 & 44.18 & $97.49 \mathrm{c}$ & $104.33 \mathrm{~b}$ & $116.71 \mathrm{a}$ \\
\hline $\begin{array}{l}\text { Vessel Number } \\
\left(\mathrm{n} \cdot \mathrm{mm}^{-2}\right)\end{array}$ & 34.64 & 50.96 & $14 \mathrm{a}$ & II c & $13 \mathrm{~b}$ \\
\hline
\end{tabular}

trees with higher degree of abiotic stress with a $31.8 \%$ difference between the range of stresses.

There is a change in the lignin content under stress conditions (MOURA et al., 20I0, MOURA-SOBCZAK et al., 20I I; LE GALL et al., 20I5, MALAVASI et al., 20I6). The adaptation occurs in regions of cell stretching, negatively affecting growth. Another hypothesis that when a plant is submitted to some stress it tends to increase the wall cell thickness by depositing lignin and hemicellulose in the secondary wall in order to avoid damages in those structures

The alteration of the lignin content was mentioned during stressful conditions, suggesting that several abiotic agents have the capacity to express the genes responsible for their synthesis (MALAVASI et al., 2016).

However, the lowest lignin content found in level III woods indicates that there was not waste of energy in structural components due to witches' brooms have caused the growth of little branches with lower weight to tree crown.

Concerning pentosan content, there was little variation across physiological disorder levels. In this regard, this result is consistent with values found by Mokfienski et al (2008) and also Longue Júnior and Colodette (20I I) who tested eucalyptus under normal conditions of growth. Another study revealed that water stress diagnosed in Fagus sylvatica in 2003 radially decreased the carbohydrate content in growth rings of adult wood; however, in peripheral rings reserves were sustained (Gérard; Breda, 20l4). Chantuma et al. (2009), on the other hand, reported that under stress conditions there is reallocation of carbohydrates from leaves to stem as a passive means of energetic accumulation and reduction.

The highest values of ashes content found in woods from level I and III are likely responses from trees that store minerals that corroborate with the chemical soil tests. In two soil profiles, lower cations concentration and base saturation were found, indicating removal of soil nutrients and plant accumulation as reported by Andrade et al. (20 I 3) and resulting in storage of macronutrients in the top.

The wall cell thickness, fiber length, and vessel diameter were larger in woods with level III physiological disorder. According to Shmulsky and Jones (20I I), when there is physiological disorder, the terminal growth, auxin production, and wood cell growth are reduced, which probably result in higher thickening in fibers even years after the disorder occurrence.

The witches' brooms in trees from level III tend to intensify the photosynthetic process and consequently the thickening in wall cell. This is because the components from photosynthesis are used to form new shoots. Subsequently, 
the organic components synthetized by leaves are made available to wood formation, in order to ensure that these formed cells will exhibit thicker walls (LARSON et al., 200I).

In spite of this, normal growth patterns are resumed during times of lower rainfall index, and new cells again grow in length as observed in the level III disorder. In this process, the seasonality and environmental conditions play important roles in the hormonal rates of control due to cambium cell divisions that influence in fiber length growth.

Cell wall thickness and fiber length increased respectively $8.5 \%$ and $12.5 \%$ in level III physiological disorder when compared to level II. On the other hand, Rodrigues (2013) has reported that wood from a lower degree of abiotic stress increased cell wall thickness by $6.1 \%$ for and fiber length by $11.9 \%$.

Wood radial profiles of apparent density exhibited variability from pith to bark for the three levels of physiological disorder (Figure 3). Dark and bright shades are related respectively to lower and higher density values. At $4.0 \mathrm{~cm}$ of the radial region, there is a similar behavior for all levels. Yet, the wood from level I stands out due to its higher homogeneity.

High values of radial variation was observed in woods from level II $\left(0.6 \mathrm{I} \mathrm{g} \cdot \mathrm{cm}^{-3}\right)$ and III $\left(0.52 \mathrm{~g} . \mathrm{cm}^{-3}\right)$, mainly at pith. However, the level I wood demonstrated high values of density variability $\left(0.53 \mathrm{~g} . \mathrm{cm}^{-3}\right)$ across its entire profile and were not concentrated at pith. High density values at pith are attached to reserve substance (carbohydrates) and crystals in parenchyma cells, according to Castro et al. (2017).

The wood from level I consumed more than $8 \%$ of reagents in kraft cooking in relation to the other levels, and it also consumed more alkali and more wood (Table 4).

Pulp yield is influenced by physiological disorder level. Compared to control at same age, disorders increased specific wood consumption and decreased the screened pulp yield, regardless of levels severity.

The hybrid from level I exhibited higher specific wood consumption, which is a result of its low density.
According reports made by Gomide et al. (2010), these two variables have a strong and negative correlation. Pulping companies continuously seek to reduce specific wood consumption even at the decimal level in order to improve pulp production and to keep chips stocked in factories.

The high extractives content in wood from level I effected the cooking by requiring more reagent loading and reduced the screened pulp yield by $5 \%$. Even though the lignin content is statistically equal among the levels, its structural characteristics could contribute to the pulp yield, considering that a higher ratio of syringyl/guaiacyl (S:G) facilitates the delignification process (Reina et al., 20I4).

The wood from level I required higher alkaline load when compared to wood from other levels even though its density did not differ statistically from level II of physiological disorder. This result diverges from research found in literature (Gomide et al., 2010; Moraes et al., 2014). They suggest that woods with lower densities require less alkaline load for cooking and demonstrate better values for screened pulp yield since carbohydrate solubilization of wood is lower.

Thus, the selections of eucalyptus species and hybrids more tolerant to environmental stresses can be an important decision to minimize effects on wood quality.

TABLE 4 Means for kraft pulping parameters of $E$. grandis $x$ E. urophylla clones diagnosed with physiological disorder.

\begin{tabular}{ccccc}
\hline \multirow{2}{*}{ Parameters } & \multicolumn{5}{c}{ Level of Physiological Disorder } \\
\cline { 2 - 5 } & $\mathrm{I}$ & $\mathrm{II}$ & $\mathrm{III}$ & Control* \\
\hline $\begin{array}{c}\text { Active Alkali } \\
(\%)\end{array}$ & 27.6 & 25.5 & 25.4 & - \\
$\begin{array}{c}\text { Total Pulp Yield } \\
(\%)\end{array}$ & 46.6 & 48.6 & 47.63 & - \\
$\begin{array}{c}\text { Screened Pulp Yield } \\
(\%)\end{array}$ & 46.4 & 48.5 & 47.6 & 51.8 \\
$\begin{array}{c}\text { Reject Level } \\
(\%)\end{array}$ & 0.20 & 0.13 & 0.02 & - \\
$\begin{array}{c}\text { Specific Wood Consumption } \\
\left(\mathrm{m}^{3} \text {.ton }\right.\end{array}$-1)
\end{tabular}

*Material made available by the company with same age and origin, at comparative level.
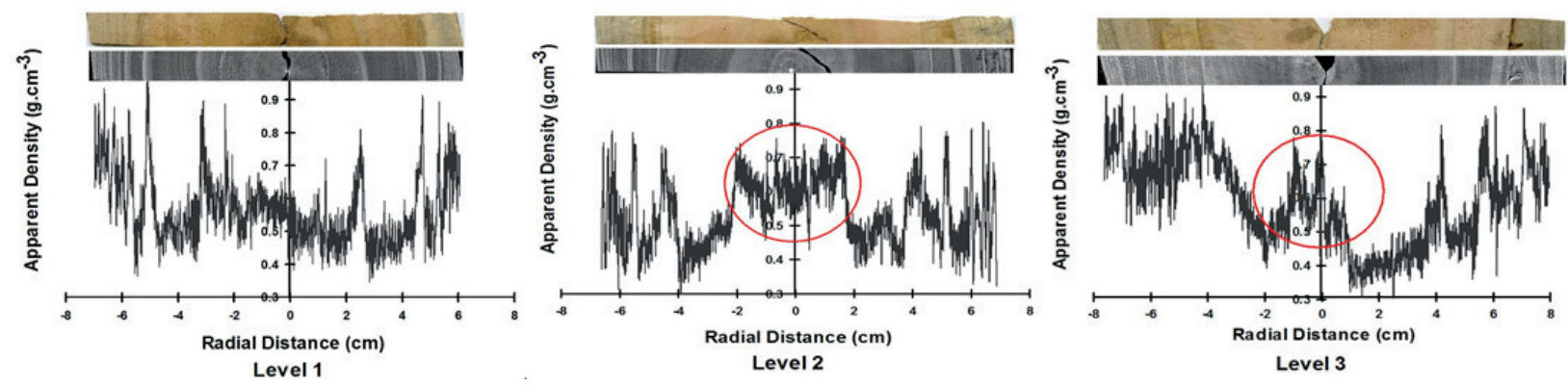

FIGURE 3 Density profiles and digital x-ray images according to physiological disorder level. 


\section{CONCLUSIONS}

The increase of severity in physiological disorder symptoms did not affect the dendrometrics variables and wood properties related to pulp production.

The wood volume of trees was positively influenced by physiological disorder severity. The trees from level III had the highest volume production when compared to other ones.

The anatomical characteristics of wood from level III trees were mainly changed with respect to vessel diameter, fiber length, and cell wall thickness.

The basic density of wood from level III was changed due to modifications found in vessels and fibers parameters. The apparent density for this wood exhibited a non-normal behavior at pith.

The extractives, soluble lignin, and ashes content proportionally varied according to physiological disorder severity.

Trees from level III exhibited changes in extractives content. The kraft pulping was favored for this tree with higher pulp yield and consequently less specific wood consumption.

\section{ACKNOWLEDGEMENTS}

To the Suzano Pulp and Paper Company (engineers: Leandro de Siqueira, Marina Valin, Heitor Dallapiccola, and Paulo Roberto Brandão) for providing the samples and the information about the experiment. The authors also wish to acknowledge the Capes (Coordination for the Development of Higher Level Personnel) for financial support.

\section{REFERENCES}

ANDRADE, A. P.; BRITO, C. C.; SILVA JÚNIOR, J.; COCOZZA, F. D. M.; SILVA, M. A. V. Estabelecimento inicial de plântulas de Myracrodruon urundeuva Allemão em diferentes substratos. Revista Árvore, v. 37, n. 4, p. 737-745, 2013.

ASSOCIAÇÃO BRASILEIRA DE NORMAS TÉCNICAS ABNT. NBR 8I I 2. Carvão vegetal - análise imediata. Rio de Janeiro, 1983.

BORZAK, C. L.; POTTS, B. M.; BARRY, K. M.; PINKARD, E. A.; O'REILLY-WAPSTRA, J. M. Genetic stability of physiological responses to defoliation in a eucalypt and altered chemical defence in regrowth foliage. Tree Physiology, v. 37, n. 2, p. 220-235, 2016.

CASTRO, V. R.; SURDI, P. G.; SETTE JUNIOR, C. R..; TOMAZELLO FILHO, M.; CHAIX, G.; LACLAU, J. P. Efeito da aplicação do potássio, do sódio e da disponibilidade hídrica na densidade aparente a I $2 \%$ de umidade do lenho juvenil de árvores de Eucalyptus grandis. Ciência Florestal, v. 27, n. 3, p. 1017-1027, 2017.
CHAGAS, R. K.; DURIGAN, G.; CONTIERI, W. A.; SAITO, M. Crescimento diametral de espécies arbóreas em floresta estacional semidecidual ao longo de seis anos. In: VILAS BOAS, O.; DURIGAN, G. Pesquisas em conservação e recuperação ambiental no Oeste Paulista: resultados da cooperação Brasil/ Japão. São Paulo: Páginas e Letras, p. 265-290, 2004.

CHANTUMA, P.; LACOINTE, A.; KASEMSAP, P.; THANISAWANYANGKURA, S.; GOHET, E.; CLÉMENT, A.; GUILLIOT, A.; AMÉGLIO, T.; THALER, P. Carbohydrate storage in wood and bark of rubber trees submitted to different level of $C$ demand induced by latex tapping. Tree Physiology, v. 29, p. 1021-1031, 2009.

COMMISION PANAMERICANA DE NORMAS TÉCNICAS COPANT. Descripción de características generales, macroscópicas de las maderas angiospermas dicotiledóneas, COPANT, v. 30, p. I-19, 1974.

GÉRARD, B.; BREDA, N. Radial distribution of carbohydrate reserves in the trunk of declining European beech trees (Fagus sylvatica L.). Annals of Forest Science, v. 7I, n. 6, p. 675-682, 2014.

GOMIDE, J. L.; FANTUZZI NETO, H.; REGAZZI, A. J. Análise de critérios de qualidade da madeira de eucalipto para produção de celulose kraft. Revista Árvore, v. 34, n. 2, p. 339-344, 2010.

GONÇALEZ, J. C.; SANTOS, G. L.; SILVA JUNIOR, F. G.; MARTINS, I. S.; COSTA, J. A. Relações entre dimensões de fibras e de densidade da madeira ao longo do tronco de Eucalyptus urograndis. Scientia Forestalis, v. 42, n. I0 I, p. $81-89,2014$.

KENNELLY, M., O'MARA, J., RIVARD, C., MILLER, G.L.; SMITH, D. Introduction to abiotic disorders in plants. The Plant Health Instructor. 20I2. From<http://www. apsnet.org/edcenter/intropp/PathogenGroups/Pages/ Abiotic.aspx $>$.

LACLAU, J. P.; GONÇALVES, J. L. M.; STAPE, J. L. Perspectives for the management of eucalypt plantations under biotic and abiotic stresses. Forest Ecology and Management, v. 30 I, p. I-5, 2013.

LARSON, P. R.; KRETSCHMANN, D. E.; CLARK, A.; ISEBRANDS, J. G. Formation and properties of juvenile wood in southern pines: a synopsis. Madison: U.S. Department of Agriculture, Forest Service, Forest Products Laboratory. 200I. 42 p.

LE GALL, H.; PHILIPPE, F.; DOMON, J. M.; GILLET, F.; PELLOUX, J.;RAYON, C. Cell wall metabolism in response to abiotic stress. Plants, v. 4, n. I, p. II2-166, 2015.

LONGUE JÚNIOR, D.; COLODETTE, J. L. Remoção de hemiceluloses da madeira por tratamento de autohidrólise. Ciência Florestal, v. 2I, n. 3, p. 54I-550, 20 II. 
PHYSIOLOGICAL DISORDERS AFFECTING DENDROMETRIC PARAMETER

MALAVASI, U. C.; DAVIS, A. S.; MALAVASI, M. M. Lignin in woody plants under water stress: a review. Floresta e Ambiente, v. 23, n. 4, p. 589-597, 2016.

MENESES, V. A.; TRUGILHO, P. F;; CALEGARIO, N.; LEITE, H. G. Efeito da idade e do sítio na densidade básica e produção de massa seca de madeira em um clone do Eucalyptus urophylla. Scientia Forestalis, v. 43, n. 105, p. I0I-I I6, 2015.

MOKFIENSKI, A.; COLODETTE, J. L.; GOMIDE, J. L.; CARVALHO, A. M. M. L. A importância relativa da densidade da madeira e do teor de carboidratos no rendimento de polpa e na qualidade do produto. Ciência Florestal, v. 18, n. 3, p. 407-419, 2008.

MORAES, F. A. B; PIRATELLI, C. L.; ACHCAR, J. A. Condições ideais para o consumo específico de madeira na produção de celulose. Production, v. 24, n. 3, p. 7|2-724, 2014.

MOURA, J. C. M. S.; BONINE, C. A. V.; VIANA, J. O. F.; DORNELAS, M. C.; MAZZAFERA, P. Abiotic and biotic stresses and changes in the lignin content and composition in plants. Journal of Integrative Plant Biology, v. 52, n. 4, p. 360-376, 2010.

MOURA-SOBCZAK, J.; SOUZA, U.; MAZZAFERA, P. Drought stress and changes in the lignin content and composition in Eucalyptus. BMC Proceedings, v. 5, n. 7, p. 103, $201 \mathrm{I}$.

PEET, M. M. Physiological Plant Disorders. Practical Hydroponics \& Greenhouses. 2016. p. 30-36.

REINA, L. R.; GALETTA, A.; VINCIGUERRA, V.; RESQUIN, F; MENÉNDEZ, P. The relationship between Eucalyptus grandis lignin structure and kraft pulping parameters. Journal of Analytical and Applied Pyrolysis, v. 107, p. 284-288, 2014.

RODRIGUES, B. P. Qualidade do lenho de árvores de clone de Eucalyptus grandis X E. urophylla sob estresse abiótico e o impacto na produção de celulose. 2013. 90 p. Dissertação, Universidade Federal do Espírito Santo, Jerônimo Monteiro.
SANTOS, R.; MELLO JÚNIOR, J. A.; CARASCHI, J. C.; VENTORIM, G.; PEREIRA, F. A. Polpação kraft e kraft/ Aq da madeira pré-hidrolisada de Eucalyptus urograndis. Ciência Florestal, v. 26, n. 4, p. I28I-I290, 2016.

SCHUTZKI, R. E.; CREGG, B. Abiotic plant disorders: symptoms, signs and solutions. Extension Bulletin, 2007. Disponível em: <http://www.oakgov.com/msu/ Documents/publications/e2996_abiotic.pdf > .

SETTE JUNIOR, C. R.; TOMAZELLO FILHO, M.; DIAS, C. T. S.; CHAGAS, M. P.; LACLAU, J. P. Efeito da aplicação de potássio e sódio nas características do lenho de árvores de Eucalyptus grandis W Hill, aos 24 meses de idade. Revista Floresta, v. 39, n. 3, p. 535-546, 2009.

SHMULSKY, R. JONES, P. D. Forest Products \& Wood Science: an introduction. 6. ed. New Jersey: WilweyBlackwell. 20I I. 483 p.

SIMONETE, M. A.; CHAVES, D. M., TEIXEIRA, C. F. A., MORO, L.; NEVES, C. U. Fornecimento de cálcio para plantas de Eucalyptus saligna por meio de aplicação de resíduo industrial lama de cal. Revista Brasileira de Ciência do Solo, v. 37, n. 5, p. |343-|35।, 2013.

STONE, C.; MATSUKI, M.; CARNEGIE, A. Pest and disease assessment in young eucalypt plantations: field manual for using the Crown Damage Index. Parsons, Bureau of Rural Sciences, Canberra, 2003.

TAPPI - TECHNICAL DIVISIONS AND COMMITTEES.TAPPI test methods, Atlanta: Tappi Press, 1998.

VELLINI, A. L. T. T.; PAULA, N. F; ALVES, P. L. C. A.; PAVANI, L. C.; BONINE, C. A. V.; SCARPINATI, E. A.; PAULA, R. C. Respostas fisiológicas de diferentes clones de eucalipto sob diferentes regimes de irrigação. Revista Árvore, v. 32, n. 4, 2008. 